\title{
Karakteristik Geokimia Organik Fraksi Keton Batubara Sawahlunto, Sumatera Barat
}

\author{
Zetra, Y. ${ }^{1}$; Amirotul, U. ${ }^{1}$, Nugraheni, Z.V. ${ }^{1}$; Burhan, R.Y. Perry ${ }^{1 *}$ \\ ${ }^{1}$ Departemen Kimia, Institut Teknologi Sepuluh Nopember (ITS). Kampus ITS Sukolilo, Surabaya \\ ${ }^{2}$ Sekolah Tinggi Energi dan Mineral Akamigas (STEM Akamigas) Cepu \\ *Penulis korespondensi : pburhan@gmail.com
}

\begin{abstract}
Batubara Sawahlunto, Sumatera Barat dianalisis untuk menentukan karakter geokimia organiknya. Batubara diekstraksi soxhlet dengan pelarut diklorometana:metanol (93:7). Hasil ekstrak organik difraksinasi menggunakan kromatografi kolom. Fraksi keton kemudian dianalisis menggunakan Kromatografi Gas-Spektrometri Massa (KG-SM). Analisis fraksi keton batubara Sawahlunto menunjukkan keberadaan senyawa iso dan anteiso-alkan-2-on, dan isoprenoid keton. Senyawa ini diasumsikan berasal dari rantai klorofil-a pada bakteri. Senyawa hopanon dan sikloheksil keton menunjukkan asal usul batubara dari bakteri. Peringkat kematangan batubara Sawahlunto adalah rendah dikarenakan terdapat senyawa hopanon pada batubara Sawahlunto. Proses kematangan batubara juga dapat terhambat jika komponen yang ada pada batubara berikatan dengan oksigen.
\end{abstract}

Kata kunci: Batubara Sawahlunto, biomarka, fraksi keton.

\begin{abstract}
Coal from Sawahlunto, West Sumatera were analyzed to determine the characters of organic geochemistry. Coals were extracted by Soxhlet method with a mixture of diclorometane:methanol (93:7) as a solvent. The extracts were fractionated using column chromatography. Ketone fractions were analyzed by Gas Chromatography-Mass Spectrometry (GC-MS). The Analysis of ketones fraction show the presence of isoprenoid ketones, iso and anteiso-alkan-2-one. These compound were expected formed by oxidation of $\alpha$ chlorophil in the bacteria. Hopanoids ketone and cyclohexyl ketones show that coal was formed from bacteria. Sawahlunto coal is belong to low rank coal because there is a presence of hopanoids ketone. Hopanoids ketone can inhibit the process of coal maturation. The process of coal maturation also inhibited by coal's compounds and oxygen bonding.
\end{abstract}

Keywords: Sawahlunto coal, biomarker, ketone fraction.

\section{Pendahuluan}

Batubara merupakan bahan bakar fosil berasal dari sumber bahan organik yang terpendam sejak jutaan tahun lalu. Indonesia merupakan salah satu negara yang mempunyai cadangan batubara yang cukup besar. Pulau Sumatera merupakan salah satu provinsi di ndonesia yang mempunyai cadangan batubara yang melimpah, yaitu sebesar $13.783,65$ juta ton per 1 Januari 2011 [1]. Batubara di Sumatera cocok untuk dieksplorasi karena letaknya yang berada di cekungan tersier. Cekungan tersier di pulau Sumatera salah satunya berada di provinsi Sumatera Barat khususnya di daerah Sawahlunto yang terletak sekitar $100 \mathrm{~km}$ kearah timur laut dari kota Padang. Dalam kerangka geologi regional daerah Sawahlunto termasuk ke dalam cekungan Ombilin yang terbentuk sejak awal tersier [2].

Setiap batubara memiliki karakteristik yang berbeda-beda berdasarkan lingkungan dan waktu pemendaman sehingga menghasilkan batubara 
dengan kualitas yang berbeda pula. Kualitas batubara ditentukan oleh kandungan mineral, senyawa organik serta nilai kalori sebagai tolak ukur kematangannya. Batubara Sawahlunto yang memiliki umur lebih tua (terbentuk pada periode Eosen) seharusnya memiliki peringkat kematangan yang tinggi.

Salah satu parameter kematangan batubara dapat diketahui dari nilai kalornya. Dilihat dari nilai kalornya, batubara Sawahlunto memiliki kematangan yang rendah. Hal ini tidak sesuai dengan kajian berdasarkan zaman pemendamannya. Selain itu, batubara ini juga termasuk dalam kelompok batubara muda jika dilihat dari nilai kalorinya, sedangkan endapan batubara lain yang masih berada pada satu cekungan memiliki kandungan kalori yang lebih tinggi. Kandungan kalori batubara yang berasal dari cekungan Sawahlunto berkisar antara 5300$6900 \mathrm{kkal} / \mathrm{kg}$. Kualitas batubara tersebut menunjukkan bahwa terdapat perbedaan pada proses serta lingkungan pemendamannya. Karakteristik batubara dapat dikaji melalui analisis biomarka untuk mengetahui asal usul sumber bahan organik pembentuk batubara serta kondisi lingkungan pengendapannya [3].

Biomarka merupakan fosil molekul yang berasal dari senyawa turunan organisme hidup pada zaman dahulu yang mengandung komponen organik kompleks berupa karbon, hidrogen dan unsur-unsur lainnya. Selama proses pembentukan batubara sebagian biomakromolekul dari organisme yang mati akan berubah menjadi batubara, sedangkan sebagian kecil lainnya akan tetap mengendap menjadi biomarka [4]. Salah satu biomarka adalah senyawa keton yang dapat terbentuk dengan adanya oksigen pada tahap diagenesis.

Biomarka senyawa keton dapat memberikan informasi sumber masukan bahan organik, kondisi lingkungan selama pemendaman berlangsung serta kematangan batubara [5-7]. Dalam penelitian sebelumnya Tuo dan Li (2005) [6] menemukan adanya senyawa keton pada batubara yang diambil dari Cekungan Dingxi, Cina, adanya senyawa keton ini mengindikasikan bahwa sampel batubara tersebut belum matang, sumber bahan organik pembentuk batubara berasal dari tumbuhan tingkat tinggi serta selama proses pembentukannya dibantu oleh mikroba. Senyawa keton yang berupa n-alkana-2-on tak jenuh jika ditemukan dalam batubara dapat menunjukkan bahwa secara geologi sampel tersebut berasal dari sedimen laut dan danau [8]. Pada sampel bitumen tasmanit terdapat senyawa $\mathrm{C} 13$ dan $\mathrm{C} 18$ isoprenoid keton yang memberikan informasi bahwa sampel berasal dari fitol dan ditemukan juga senyawa metil keton rantai lurus yang terbentuk dari $\beta$-oksidasi pada senyawa alkana yang sesuai [9]. Senyawa triterpenoid yang terdapat pada sedimen lebih rentan mengalami degradasi daripada senyawa hopanoid. Hal tersebut dikarenakan keberadaan gugus fungsi (alkohol, keton) pada posisi C-3 dalam senyawa triterpenoid (misalnya $\beta$-amirin, $\beta$-amirenon) [10]. Senyawa hopanon yang ditemukan dalam batubara juga dapat mengindikasikan peringkat kematangan batubara yang rendah dikarenakan sulit untuk terdegradasi [11].

Perbedaan peringkat kematangan batubara Sawahlunto yang tidak sesuai dengan teori memerlukan kajian lebih lanjut. Analisis biomarka terhadap batubara ini dapat memberikan informasi mengenai sumber senyawa pembentuk batubara, lingkungan serta kondisi pengendapannya. Hal tersebut mendorong dilakukannya penelitian tentang karakteristik batubara Sawahlunto yang meliputi sumber senyawa pembentuk batubara, lingkungan serta kondisi pengendapannya melalui analisis biomarka.

\section{Metode Penelitian}

\subsection{Uji Pendahuluan}

Sampel batubara Sawahlunto sebelum digunakan dalam proses analisis biomarka dilakukan pengujian nilai kalori terlebih dahulu. Sebanyak 0,2 gram butiran batubara yang telah kering dimasukkan ke dalam bom kalorimeter. Hasil yang diperoleh berupa nilai kalori per satuan gram sampel.

\subsection{Ekstraksi Batubara}

Sampel batubara Sawahlunto dihaluskan menggunakan lumpang beserta mortarnya hingga diameter butiran sampel berukuran 100 mesh. Sebanyak 9 gram batubara Sawahlunto diekstraksi menggunakan metode soxhlet mengikuti metode Fardaduzzaman, dkk. (2012) [12]. Pelarut yang digunakan merupakan campuran diklorometana:metanol (93:7) dengan pemanasan pada suhu $40^{\circ} \mathrm{C}$. Ekstrak organik yang diperoleh kemudian dipekatkan dari pelarutnya menggunakan vacuum rotary evaporator, kemudian dialiri gas $\mathrm{N}_{2}$ hingga diperoleh ekstrak organik kering. 


\subsection{Fraksinasi Ekstrak Organik}

Sebanyak 0,5 gram ekstrak organik yang diperoleh difraksinasi dengan menggunakan kromatografi kolom yang menggunakan silika gel sebagai fase diamnya. Fraksinasi ini digunakan untuk memisahkan campuran dari ekstrak bahan organik sehingga didapatkan fraksi keton.

Eluen yang digunakan dalam proses fraksinasi ini dirujuk dari metode Widodo, dkk. (2009) [13] yang menggunakan pelarut diklorometana untuk memperoleh fraksi keton. Fraksi yang diperoleh dipekatkan dari pelarutnya menggunakan vacuum rotary evaporator. Selanjutnya, fraksi tersebut dialiri gas $\mathrm{N}_{2}$ sehingga diperoleh fraksi keton pekat batubara Sawahlunto. Fraksi keton kemudian dianalisis menggunakan Kromatografi Gas-Spektrometri Massa (KG-SM).

\subsection{Analisis Kromatografi Gas-Spektrometri Massa (KG-SM)}

Satu miligram sampel fraksi keton yang diperoleh dari proses fraksinasi dilarutkan dalam dalam $1 \mathrm{~mL}$ pelarut diklorometana. Lalu diambil $0,5 \mu \mathrm{L}$ untuk diinjeksikan ke dalam instrumen KG-SM. Kromatografi gas yang digunakan adalah Kromatografi Gas Agilent yang dihubungkan ke Spektrometri Massa Agilent 122-5561. Kromatografi gas dilengkapi dengan kolom kapiler yang berisi butiran silika DB-5 MS (60 m x $0,25 \mathrm{~mm}$ ID x $0,10 \mu \mathrm{m}$ ), gas pembawa yang digunakan adalah Helium. Kondisi analitik yang dipakai yaitu pengaturan suhu kolom seperti berikut: suhu awal $70{ }^{\circ} \mathrm{C}$ selama 1 menit kemudian diprogram dari suhu $70{ }^{\circ} \mathrm{C}$ sampai $150{ }^{\circ} \mathrm{C}$ dengan kenaikkan suhu sebesar $10{ }^{\circ} \mathrm{C} /$ menit, lalu suhu dinaikkan lagi dengan laju kenaikan sebesar $2^{\circ} \mathrm{C} /$ menit sampai suhu $290^{\circ} \mathrm{C}$ dan dari 290-315 ${ }^{\circ} \mathrm{C}$ dengan laju kenaikan $5{ }^{\circ} \mathrm{C} /$ menit dengan isotermal selama 30 menit pada $315{ }^{\circ} \mathrm{C}$. Spektra massa yang diperoleh melalui pengamatan dari $\mathrm{m} / \mathrm{z} 50$ sampai 550 dengan energi ionisai sebesar $70 \mathrm{eV}$ dianalisis menggunakan rujukan dari penelitian sebelumsebelumnya. Seluruh puncak pada kromatogram diidentifikasi berdasarkan hasil fragmentogram yang diperoleh dan diinterpresentasikan sehingga diperoleh struktur senyawa hidrokarbon yang ada pada sampel tersebut.

\section{Hasil dan Pembahasan}

\subsection{Uji Pendahuluan}

Sampel batubara yang telah kering ditimbang sebanyak 0,2 gram dan dimasukkan ke dalam bom kalori meter. Uji pendahuluan digunakan untuk menentukan nilai kalori batubara sebelum digunakan dalam proses analisis biomarka. Nilai kalori yang diperoleh dapat digunakan untuk menentukan peringkat kematangan batubara. Hasil pengujian ini menunjukkan nilai kalori batubara Sawahlunto sebesar $3674 \mathrm{kal} / \mathrm{g}$. Berdasarkan hasil tersebut, batubara Sawahlunto belum termasuk batubara lignit atau dapat dikatakan memiliki peringkat kematangan yang sangat rendah.

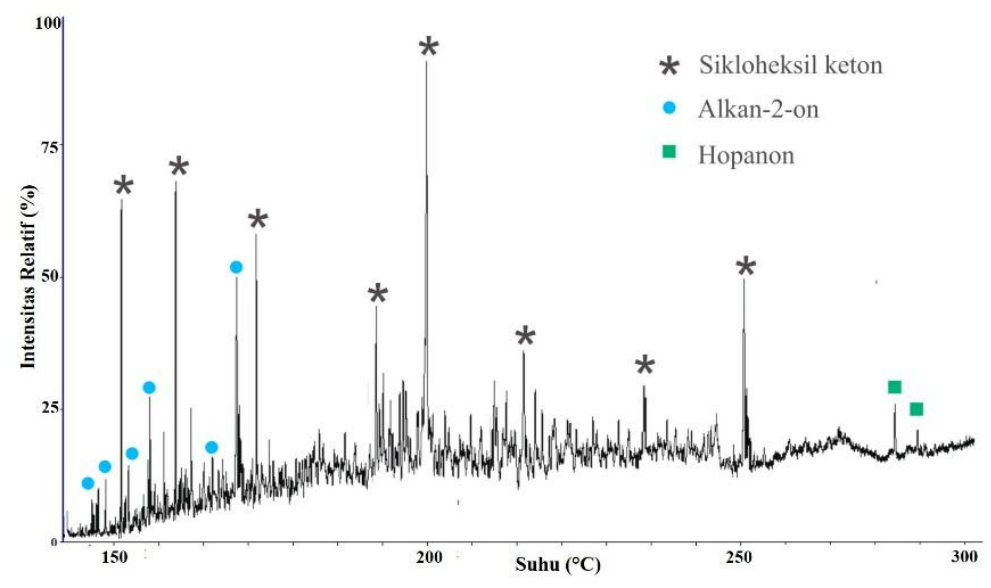

Gambar 1 Kromatogram ion total fraksi keton batubara Sawahlunto

Kondisi KG-SM: kolom kapiler leburan silika DB-5, gas pembawa Helium. Program suhu: $70^{\circ} \mathrm{C}$ (ditahan 1 menit) sampai $150^{\circ} \mathrm{C}$ dengan $10^{\circ} \mathrm{C} /$ menit, $150-290^{\circ} \mathrm{C}$ dengan $2{ }^{\circ} \mathrm{C} /$ menit dan 290 sampai $315^{\circ} \mathrm{C}$ (ditahan 6 menit) dengan $5^{\circ} \mathrm{C} /$ menit. 


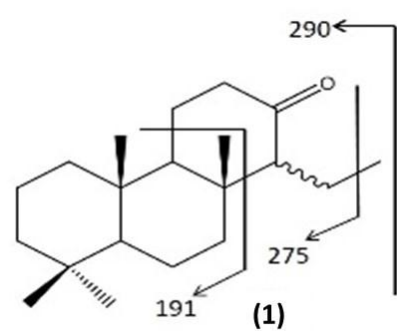

(1)<smiles>CC(=O)CC(C)(C)CCC1(C)CCC1(C)CC(C)(C)CC(C)C(C)(C)C</smiles>

(3)

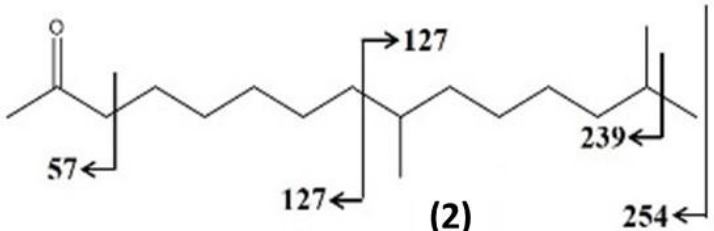

(2)

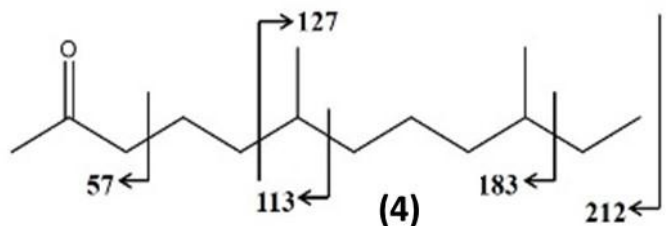

(4)

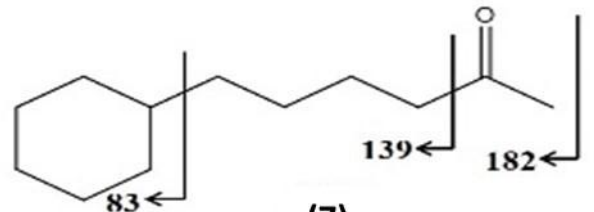

(7)

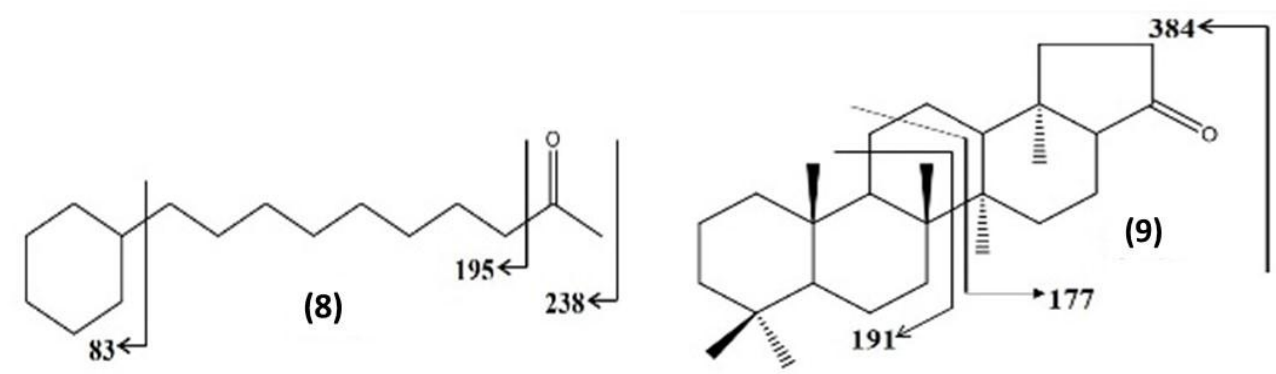

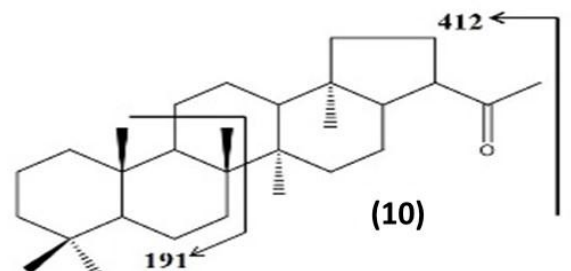

Gambar 2. Struktut senyawa/fragmen yang dihasilkan

\subsection{Ekstraksi Batubara}

Ekstrak batubara yang diperoleh berupa cairan berwarna kuning kecoklatan kemudian diuapkan pelarutnya atau dipekatkan dengan menggunakan alat vacum rotary evaporator. Ekstrak pekat tersebut kemudian dipindahkan ke dalam botol 
vial dan dikeringkan dengan dialiri gas $\mathrm{N}_{2}$ sehingga diperoleh ekstrak organik kering dengan massa 0,6434 gram (7,12\%). Ekstrak kering yang didapatkan merupakan ekstrak organik total (EOT). Ekstrak organik total dari batubara Sawahlunto yang didapatkan sedikit karena batubara Sawahlunto masih banyak mengandung kerogen yang merupakan bahan organik dalam batubara yang tidak dapat larut didalam pelarut organik.

\subsection{Pemisahan Ekstrak Batubara}

Ekstrak Organik Total (EOT) yang telah didapatkan dari proses ekstraksi soxhletasi selanjutnya difraksinasi untuk mendapatkan fraksi keton dengan menggunakan metode kromatografi kolom. Hasil fraksinasi selanjutnya dianalisis untuk memperoleh profil biomarkanya. Kolom kromatografi yang digunakan merupakan kolom yang berisi silika gel sebagai fase diam dan telah dijenuhkan dengan $n$-heksana, sebagian silika gel yang digunakan diimpregnasi dahulu dengan ekstrak organik yang telah dilarutkan dalam kloroform. Pengontrolan turunnya masing-masing fraksi dilakukan dengan melakukan pengujian pada noda eluen yang dipakai dibandingkan dengan tetesan hasil kromatografi kolom. Jika totolan antara noda eluen dan noda hasil kromatografi menunjukkan noda yang sama dibawah sinar UV maka proses pemisahan menggunakan kromatografi kolom telah selesai. Hasil fraksinasi ditampung dalam labu bundar kemudian diuapkan pelarutnya menggunakan rotary evaporator lalu dipindah ke dalam botol vial dan dikeringkan menggunakan gas $\mathrm{N}_{2}$. Fraksinasi dengan kromatografi kolom menghasilkan fraksi keton sebanyak 0,1140 gram $(17,72 \%)$ berupa padatan berwarna coklat kehitaman.

\subsection{Komposisi Senyawa Biomarka Fraksi Keton Batubara Sawahlunto}

Hasil analisis fraksi keton dari ekstrak batubara Sawahlunto menggunakan KG-SM ditunjukkan seperti pada Gambar 3.1. Dari gambar tersebut dapat dilihat bahwa kelompok senyawa yang teridentifikasi pada fraksi keton batubara Sawahlunto adalah alkan-2-on, sikloheksil keton, dan hopanon. Hal ini membuktikan bahwa semua komponen tersebut mungkin berasal dari kombinasi pada saat diagenensis yang meliputi proses dekarboksilasi, siklisasi, pemecahan dan juga proses penataan ulang pada asam lemak yang bersumber dari mikroba [14].

Senyawa Alkan-2-on

Senyawa alkan-2-on bercabang yang terdapat pada fraksi keton batubara Sawahlunto diidentifikasi berdasarkan fragmentogram $\mathrm{m} / \mathrm{z} 57$ yang merupakan puncak dasar dari senyawa alkan-2-on [15]. Fragmen ion pada $\mathrm{m} / z 57$ tersebut merupakan fragmen keton yang paling stabil berupa $\left(\mathrm{C}_{3} \mathrm{H}_{5} \mathrm{O}\right)^{+}$. Spektrum massa pada senyawa alkan-2-on bercabang memiliki puncak dasar pada $\mathrm{m} / \mathrm{z} 57$ yang diikuti penurunan intensitas puncak setiap penambahan nilai sebesar 14 satuan yang merupakan penambahan gugus metilen $\left(-\mathrm{CH}_{2}{ }^{-}\right)$ sebagai perpanjangan rantai. Penurunan intensitas tidak terjadi secara linear karena saat pemutusan rantai cabang terjadi peningkatan intensitas fragmen ion. Peningkatan intensitas fragmen ion pada fragmen $\mathrm{M}^{+} \quad-15$ atau $\mathrm{M}^{+} \quad-29$ mengindikasikan adanya cabang metil pada rantai alkana posisi $\mathrm{C}_{2}$ (iso-alkana) atau $\mathrm{C}_{3}$ (anteisoalkana) [16]. Pemutusan rantai cabang juga mengakibatkan pertambahan nilai 14 yang tidak konstan karena saat terjadi penambahan gugus etilen $\left(-\mathrm{C}_{2} \mathrm{H}_{4}-\right)$ maka nilainya akan bertambah sebesar 28 satuan massa atom.

Interpretasi spektrum massa puncak $\mathrm{C}_{12}$ memiliki puncak dasar pada $\mathrm{m} / \mathrm{z} \quad 57$ dan menghasilkan ion molekular pada m/z 184 . Adanya peningkatan intensitas pada fragmen ion $\mathrm{m} / \mathrm{z} 155$ terjadi akibat lepasnya gugus etil $\left(\mathrm{C}_{2} \mathrm{H}_{5}\right) \cdot$ serta mengindikasikan bahwa terdapat cabang metil pada atom karbon nomor 9, sehingga dapat diketahui bahwa senyawa tersebut merupakan senyawa anteiso-alkanon yaitu senyawa 9metilundekan-2-on $\left(\mathrm{C}_{12} \mathrm{H}_{24} \mathrm{O}\right)(\mathbf{1})$.

Interpretasi yang sama juga dilakukan pada spektrum massa puncak $\mathrm{C}_{17}$ yang memiliki puncak dasar pada $\mathrm{m} / \mathrm{z} 57$ serta menghasilkan ion molekular pada $\mathrm{m} / \mathrm{z} 254$ dengan adanya peningkatan intensitas pada fragmen ion $\mathrm{m} / \mathrm{z} 127$ yang menandakan adanya cabang pada $\mathrm{C} 9$ dan pada fragmen ion $\mathrm{m} / \mathrm{z} 239$ akibat lepasnya gugus metil $\left(\mathrm{CH}_{3}\right) \cdot$ yang mengindikasikan adanya cabang metil pada atom karbon nomor 14, sehingga dapat diketahui bahwa senyawa tersebut merupakan senyawa iso-alkanon yaitu senyawa 9,14-dimetilpentadekan-2-on $\quad\left(\mathrm{C}_{17} \mathrm{H}_{34} \mathrm{O}\right) \quad$ (2). Senyawa iso- dan anteiso-alkana telah diisolasi dari beberapa sumber termasuk bakteri, tanaman tingkat tinggi, dan beberapa sedimen baik sedimen baru ataupun sedimen purba. Adanya seri 
homolog pada iso- dan anteiso-alkana disertai dengan tingginya jumlah karbon ganjil mengindikasikan adanya kontribusi lilin dari tanaman [16]. Namun pada batubara Sawahlunto tidak ditemukan adanya seri homolog dari isoataupun anteiso-alkanon.

Interpretasi yang sama juga dilakukan pada spektrum massa puncak $\mathrm{C}_{13}, \mathrm{C}_{14}, \mathrm{C}_{15}$, dan $\mathrm{C}_{18}$. Senyawa isoprenoid merupakan senyawa yang terbentuk dari beberapa senyawa isoprena $\left(\mathrm{C}_{5}\right)$ yang saling terhubung. Isoprenoid umum yang memiliki kelimpahan paling banyak merupakan isoprenoid yang dihubungkan dari kepala ke ekor termasuk didalamnya yaitu senyawa pristan $\left(\mathrm{C}_{19}\right)$ dan fitan $\left(\mathrm{C}_{20}\right)$ [16].

Interpretasi spektrum massa menghasilkan ion molekular pada m/z 198 dengan disertai peningkatan puncak pada $\mathrm{m} / \mathrm{z} 113$ dan penambahan nilai sebesar 28 satuan pada $\mathrm{m} / \mathrm{z} 155$ yang menunjukkan penambahan gugus etilen $\left(\mathrm{C}_{2} \mathrm{H}_{4}\right)$. Hal tersebut menunjukkan bahwa terdapat cabang pada posisi $\mathrm{C}_{6}$ dan $\mathrm{C}_{10}$ maka senyawa yang ada pada gambar tersebut adalah senyawa 6,10-dimetilundekan-2-on $\quad\left(\mathrm{C}_{13} \mathrm{H}_{26} \mathrm{O}\right) \quad$ (3). Spektrum massa dengan ion molekular pada $\mathrm{m} / \mathrm{z}$ 212 terjadi peningkatan fragmen ion pada m/z 113 dan $\mathrm{m} / \mathrm{z} 183$ yang menunjukkan adanya cabang metil pada rantai $C_{6}$ dan $C_{10}$ sehingga senyawa pada puncak $\mathrm{C}_{14}$ adalah senyawa 6,10dimetildodekan-2-on $\quad\left(\mathrm{C}_{14} \mathrm{H}_{28} \mathrm{O}\right) \quad$ (4). Pada spektrum massa juga terjadi peningkatan puncak fragmen ion pada m/z 113 dan $\mathrm{m} / \mathrm{z} \quad 183$ menandakan adanya cabang pada $\mathrm{C}_{6}$ dan $\mathrm{C}_{10}$, senyawa ini memiliki ion molekular pada $\mathrm{m} / \mathrm{z} 226$ sehingga dapat diketahui senyawanya adalah 6,10dimetiltridekan-2-on $\left(\mathrm{C}_{15} \mathrm{H}_{30} \mathrm{O}\right)$ (5). Dengan cara interpretasi yang sama pada puncak $\mathrm{C}_{18}$ yang memiliki ion molekular pada $\mathrm{m} / \mathrm{z} 268$ dapat diketahui terdapat tiga cabang metil yaitu pada posisi $\mathrm{C}_{6}, \mathrm{C}_{10}$, dan $\mathrm{C}_{14}$ maka senyawa tersebut adalah 6,10,14-trimetilpentadekan-2-on $\left(\mathrm{C}_{18} \mathrm{H}_{36} \mathrm{O}\right)$ (6).

Senyawa 6,10,14-trimetilpentadekan-2-on di alam terjadi secara luas dalam sedimen. Isoprenoid keton ini dapat terbentuk dari senyawa pristana yang mengalami oksidasi fotosintesis dan senyawa fitol yang didegradasi oleh bakteri [6]. Senyawa ini juga dapat berasal dari rantai klorofil- $\alpha$ yang mengalami oksidasi dalam lingkungan akuatik [17].

Beberapa senyawa isoprenoid keton $\left(\mathrm{C}_{13}, \mathrm{C}_{14}\right.$, $\mathrm{C}_{18}, \mathrm{C}_{19}$ ) juga ditemukan dalam sampel batu kapur yang diambil dari Hokkaido pusat, Jepang dengan didominasi isoprenoid keton $\mathrm{C}_{13}$ dan $\mathrm{C}_{18}$. Keberadaan beberapa isoprenoid keton tersebut diasumsikan berasal dari lemak anaerobic methanotrophic archaea (ANME) [18]. Senyawa 6,10-dimetil-undekan-2-on (isoprenoid keton $\mathrm{C}_{13}$ ) dan 6,10,14-trimetil-pentadekan-2-on (isoprenoid keton $\mathrm{C}_{18}$ ) yang terdapat dalam sampel bitumen tasmanit Tasmanian diasumsikan berasal dari fitol, sedangkan 6,10-dimetil-dodekan-2-on (isoprenoid keton $\mathrm{C}_{14}$ ) dan 6,10,14-trimetil-oktadekan-2-on (isoprenoid keton $\mathrm{C}_{19}$ ) berasal dari oksidasi ikatan rangkap pada rantai trisiklooktaprenol atau trisiklooktaprenena yang merupakan komponen pada membran bakteri [19]. Fotodegradasi senyawa klorofil- $\alpha$ yang terjadi dalam lingkungan air laut juga dapat menghasilkan isoprenoid keton 6,10-dimetilundekan-2-on dan 6,10,14trimetilpentadekan-2-on. Kedua senyawa ini sering ditemukan dalam lingkungan laut [20]. Keberadaan senyawa isoprenoid keton pada batubara Sawahlunto mengindikasikan bahwa sumber bahan organik pembentuk batubara Sawahlunto berasal dari bakteri berklorofil.

\section{Senyawa Sikloheksil Keton}

Keberadaan senyawa sikloheksil keton pada fraksi keton batubara Sawahlunto diidentifikasi berdasarkan fragmentogram $\mathrm{m} / \mathrm{z} \quad 83$ yang merupakan puncak dasar dari senyawa siklik. Puncak dasar pada $\mathrm{m} / \mathrm{z} 83$ tersebut merupakan fragmen fraksi keton yang paling stabil berupa cincin siklik enam $\left(\mathrm{C}_{6} \mathrm{H}_{11}\right)^{+}$fragmen ini terbentuk karena cincin siklo yang bersifat jenuh akan cenderung melepaskan rantai samping alkil pada ikatan- $\alpha$ dan meninggalkan muatan positif pada fragmen cincin siklo.

Interpretasi spektrum massa fraksi keton pada puncak $\mathrm{C}_{12}$ menunjukkan adanya puncak tertinggi pada $m / z 83$ dengan disertai penurunan intensitas puncak secara linear pada $\mathrm{m} / z$ 97, 111, 125 dan seterusnya hingga $\mathrm{m} / \mathrm{z} \quad 182$ sebagai ion molekulnya dengan penambahan nilai sebesar 14 yang merupakan perpanjangan rantai -berupa gugus metilen $\left(-\mathrm{CH}_{2}-\right)$ sehingga dapat diketahui bahwa senyawa tersebut adalah 6sikloheksilheksan-2-on $\left(\mathrm{C}_{12} \mathrm{H}_{22} \mathrm{O}\right)$ (7). Spektrum massa fraksi keton pada puncak $\mathrm{C}_{16}$ memiliki spektrum yang serupa dengan puncak $\mathrm{C}_{12}$ dengan puncaak tertinggi pada $\mathrm{m} / \mathrm{z} 83$ dan fragmen seterusnya mengalami penurunan secara linear seiring dengan penambahan kelipatan 14 sampai pada $m / z 238$ sehingga dapat diketahui bahwa 
senyawa pada puncak $\mathrm{C}_{16}$ merupakan senyawa 10 sikloheksil-dekan-2-on $\left(\mathrm{C}_{16} \mathrm{H}_{30} \mathrm{O}\right)(\mathbf{8})$.

Senyawa sikloheksil keton yang teridentifikasi pada batubara Sawahlunto adalah puncak $\mathrm{C}_{10}, \mathrm{C}_{12}$, $\mathrm{C}_{13}, \mathrm{C}_{14}, \mathrm{C}_{16}, \mathrm{C}_{17}, \mathrm{C}_{18}$ dan $\mathrm{C}_{20}$. Sehingga dapat diketahui bahwa terdapat senyawa sikloheksil keton pada batubara Sawahlunto dengan rentang karbon antara $\mathrm{C}_{10}$ sampai $\mathrm{C}_{20}$ dengan dominasi $\mathrm{C}$ genap dan puncak tertinggi pada $\mathrm{C}_{16}$. Senyawa alkilsikloheksana yang ditemukan dalam beberapa sampel dengan jumlah karbon kurang dari 20 mengindikasikan bahwa sumber bahan organik sampel berasal dari asam lemak yang ada pada bakteri [14] [21-22]. Senyawa alkilsikloheksana dapat berubah menjadi senyawa sikloheksil keton melalui proses $\beta$-oksidasi yang disertai dengan bantuan bakteri [6]. Senyawa sikloheksil keton yang terdapat dalam sampel batubara memberikan kemungkinan bahwa sumber bahan organik pada batubara Sawahlunto berasal dari bakteri.

\section{Senyawa Hopanon}

Keberadaan senyawa hopanon dalam fraksi keton batubara Sawahlunto dianalisis berdasarkan fragmentogram $\mathrm{m} / \mathrm{z}$ 191. Fragmen ion khas senyawa hopan ada pada $\mathrm{m} / \mathrm{z} 191$. Konfigurasi $\alpha$ atau $\beta$ terhadap posisi $\mathrm{H}$ pada $\mathrm{C}_{17}$ dan $\mathrm{C}_{21}$ dapat diketahui berdasarkan intensitas dari fragmen ion pada $\mathrm{m} / \mathrm{z} 191$ dan $\mathrm{m} / \mathrm{z} 148+$ R. Jika intensitas $\mathrm{m} / \mathrm{z}$ $148+\mathrm{R}$ lebih tinggi daripada $\mathrm{m} / \mathrm{z} 191$ maka konfigurasi senyawa hopan adalah $17 \beta(\mathrm{H}), 21 \beta(\mathrm{H})$, sedangkan jika $\mathrm{m} / \mathrm{z} 191$ intensitasnya lebih tinggi daripada $m / z 148+\mathrm{R}$ maka konfigurasi senyawa hopan adalah $17 \alpha(\mathrm{H}), 21 \beta(\mathrm{H})[16]$.

Interpretasi spektrum massa senyawa hopanon pada puncak $\mathrm{C}_{27}$ memiliki fragmen yang paling stabil pada m/z 191 sedangkan fragmen $148+\mathrm{R}$ intensitasnya lebih rendah, pola ini menunjukkan bahwa senyawa hopanon yang teridentifikasi berupa isomer $17 \alpha(\mathrm{H}), 21 \beta(\mathrm{H})$. Puncak $\mathrm{m} / \mathrm{z} 191$ merupakan fragmen ion $\mathrm{C}_{14} \mathrm{H}_{23}{ }^{+}$dari cincin $\mathrm{A} / \mathrm{B}$ oleh pemutusan cincin $\mathrm{C}$. Fragmen khas lain yang teridentifikasi pada m/z 369 yang menandakan lepasnya cabang metil $\left(-\mathrm{CH}_{3}\right)$ dan diketahui pula 384 sebagai ion molekuar, sehingga dapat diketahui bahwa senyawa tersebut merupakan 22,29,30-trinorhopan-21-on (9) dengan konfigurasi $17 \alpha(\mathrm{H}), 21 \beta(\mathrm{H})$. Interpretasi yang sama juga dilakukan terhadap spektrum massa puncak $\mathrm{C}_{29}$ yang memiliki intensitas $\mathrm{m} / \mathrm{z} 191>$ $148+\mathrm{R}$ dan $\mathrm{m} / \mathrm{z} 412$ sebagai ion molekularnya. Dari interpretasi tersebut dapat diketahui bahwa senyawa yang teridentifikasi pada puncak $\mathrm{C}_{29}$ merupakan senyawa 30-norhopan-22-on dengan konfigurasi $17 \alpha(\mathrm{H}), 21 \beta(\mathrm{H})$.

Hopan dan turunannya merupakan kelompok senyawa yang dapat ditemukan hampir disemua sampel sedimen organik. Senyawa hopanoid digunakan sebagai penanda biomarka pada geokimia organik karena terdistribusi secara luas pada bakteri dan sianobakteri (alga hijau-biru) [23], walaupun dapat juga ditemukan pada tumbuhan lumut, jamur, alga dan beberapa tumbuhan tingkat tinggi [10][16]. Senyawa hopanoid yang berasal dari bakteri memiliki senyawa pembentuk berupa $\mathrm{C}_{35}$ bacteriohopanepolyols, senyawa ini merupakan seri utama dalam semua hopanoid yang ditemukan pada membran bakteri dan sianobakteri [24-25]

Hopanoid dengan jumlah carbon 30 atau kurang dapat berasal dari proses diagenesis $\mathrm{C}_{30}$ hopanoid, misalnya berasal dari diploptena yang ada pada beberapa organisme yang masih hidup sampai sekarang. Proses diagenesis dapat mengubah $\mathrm{C}_{30}$ hopanoid menjadi beberapa senyawa [23]. Turunan hopana berupa hopanon bisa diperoleh selama tahap diagenesis. Keberadaan senyawa hopanon memberikan informasi bahwa batubara Sawahlunto berada pada lingkungan pengendapan suboksik sampai oksik, serta proses penggambutan berada pada kondisi asam yang rendah. Kandungan senyawa ini juga menunjukkan bahwa proses degradasi pada bahan organik dilakukan oleh bakteri aerobic [11] [26].

\subsection{Aspek Geokimia Organik Batubara Sawahlunto}

Analisa biomarka fraksi keton terhadap batubara Sawahlunto menunjukkan senyawa yang teridentifikasi pada batubara Sawahlunto meliputi $\mathrm{C}_{12}$ anteiso-alkan-2-on, $\mathrm{C}_{17}$ iso-alkan-2-on, isoprenoid keton $\left(\mathrm{C}_{13}, \mathrm{C}_{14}, \mathrm{C}_{15}, \mathrm{C}_{18}\right)$, sikloheksil keton $\left(\mathrm{C}_{10}, \mathrm{C}_{12}, \mathrm{C}_{13}, \mathrm{C}_{14}, \mathrm{C}_{15}, \mathrm{C}_{16}, \mathrm{C}_{17}, \mathrm{C}_{18}, \mathrm{C}_{20}\right)$ dan hopanon $\left(\mathrm{C}_{27}\right.$ dan $\left.\mathrm{C}_{29}\right)$.

Analisa biomarka yang dilakukan pada batubara Sawahlunto memberikan informasi mengenai sumber bahan organik pembentuk batubara dan peringkat kematangan batubara. Batubara Sawahlunto memiliki sumber bahan organik yang berasal dari bakteri. Hal ini dapat diinterpretasi berdasarkan adanya senyawa isoprenoid keton, sikloheksil keton dan hopanon. Kematangan batubara Sawahlunto dapat diketahui dari senyawa hopanon yang teridentifikasi pada 
konfigurasi $\alpha \beta$. Keberadaan senyawa hopanon dengan konfigurasi $\alpha \beta$ menunjukkan bahwa batubara telah matang secara termal dan telah melewati tahap diagenesis. Senyawa hopan juga dapat digunakan sebagai penanda lingkungan pengendapan, sehingga diketahui bahwa batubara Sawahlunto terendapkan pada lingkungan suboksik sanpai oksik. Informasi mengenai kematangan batubara Sawahlunto juga dapat diketahui melalui nilai kalori batubara sebesar $3674 \mathrm{kal} / \mathrm{g}$. Batubara dengan nilai kalori tersebut belum termasuk dalam batubara lignit serta menunjukkan bahwa batubara memiliki peringkat kematangan yang sangat rendah meskipun telah matang secara termal.

Keberadaan senyawa hopanon dalam batubara Sawahlunto dapat menghambat proses kematangan batubara. Senyawa hopanoid dalam sedimen lebih sulit terdegradasi dari pada senyawa $\beta$-amirin yang memiliki gugus fungsi pada posisi C-3. Hal ini menjadikan batubara Sawahlunto memiliki nilai kalor yang rendah. Perbedaan peringkat kematangan batubara Sawahlunto terhadap batubara pada cekungan yang sama dimungkinkan karena komponen pada batubara berikatan dengan oksigen atau ikatan antar komponennya dihubungkan oleh oksigen. Hal ini dapat menghambat proses kematangan batubara karena komponen yang berikatan dengan oksigen akan lebih sulit untuk membentuk senyawa yang lebih stabil. Seperti senyawa amirenon pada batubara Tarakan yang seharusnya melepas gugus fungsinya membentuk senyawa yang lebih stabil yaitu oleanena selama tahap diagenesis.

\section{Kesimpulan}

Analisa biomarka terhadap fraksi keton batubara Sawahlunto, Sumatera Barat memberikan informasi mengenai komposisi senyawa yang terkandung. Kandungan senyawa biomarka pada batubara Sawahlunto meliputi senyawa anteiso dan iso-alkan-2-on, isoprenoid keton, sikloheksil keton dan hopanon. Batubara Sawahlunto merupakan batubara yang berasal dari kontribusi bakteri dan terendapkan pada lingkungan suboksik sampai oksik. Batubara ini memiliki kualitas yang sangat rendah. Keberadaan senyawa hopanon dalam batubara Sawahlunto dapat menghambat proses kematangan batubara karena lebih sulit terdegradasi dari pada senyawa $\beta$-amirin yang memiliki gugus fungsi pada posisi C-3. Faktor lain yang menghambat kematangan batubara karena komponen pada batubara berikatan dengan oksigen atau ikatan antar komponennya dihubungkan oleh oksigen.

Ucapan Terimakasih

Ucapan terimakasih penulis tujukan kepada Laboratorium Geokimia Molekular, Departemen Kimia, FMIPA, ITS.

\section{Daftar Pustaka}

[1] Syahrial, E., Adam, R., Suharyati, Ajiwihanto, N., Indrawati, R. R. F., Kurniawan, F., Kurniawan, A., Suzanti, Vony M., "Handbook of Energy \& Economic Statistics of Indonesia" Pusdatin ESDM, Indonesia, 2012.

[2] Cahyono, Eko B., "Pemboran Dalam dan Evaluasi Potensi CBM Daerah Sawahlunto, Provinsi Sumatera Barat". Prosiding Hasil Kegiatan Pusat Sumber Daya Geologi Tahun 2011, 2011.

[3] Hunt, John M., Philp, R. P., Kvenvolden, Keith A., "Early Developments in Petroleum Geochemistry", Organic Geochemistry, 2002, vol. 32, pp. 1025-1052.

[4] Peters, Kenneth E., dan Moldowan, S. M., "The Biomarkers Guide Interprenting Molecular Fossil in Petroleum and Sediment", Prentice Hall, Inc. New Jersey, 1993.

[5] Leif, R. N., dan Simoneit, B. R. T., "Ketones in Hydrothermal Petroleums and Sediment Extracts from Guaymas Basin, Gulf of California", Organic Geochemistry, 1995, vol. 23, pp. 889904.

[6] Tuo, J. dan Li, Q., “Occurrence and Distribution of Long-chain Acyclic Ketones in Immature Coals", Applied Geochemistry, 2005, vol. 20, pp. 553-568.

[7] Wilkes, H., Disko, U., Horsfield, B., "Aromatic Aldehydes and Ketones in the Posidonia Shale, Hils Syncline, Germany", Organic Geochemistry, 1998, vol. 29, pp. 107-117.

[8] Rieley, G., Collier, R. J., Jones, D. M., Eglinton, G., "The Biogeochemistry of Ellesmere Lake, U.K.-I: Source Correlation of Leaf Wax Inputs to the Sedimentary Lipid Record", Organic Geochemistry, 1991, vol. 17, pp. 901-912.

[9] Azevedo, D. A., Zinu, C. J. A., Neto, F. R. A., Simoneit, B. R. T., "Possible Origin of Acyclic (Linear and Isoprenoid) and Tricyclic Terpane Methyl Ketones in a Tasmanian Tasmanite Bitumen", Organic Geochemistry, 2001, vol. 32, pp. 443-448.

[10] Stenova, M., Ivanov, D., Yaneva, N., Marinov, S., Grasset, L., dan Ambles, A., "Palaeoenvironment Assessment of Pliocene Lom Lignite (Bulgaria) from Bitumen Analysis and Preparative Off Line Thermochemolysis", Organic Geochemistry, 2008, vol. 39, pp. 1589-1605. 
[11] Zivotic, D., Stojanovic, K., Grzetic, I., Jovancicevic, B., Cvetkovic, O., Sajnovic, A., Simic, V., Stojakovic, R., dan Scheeder, G., "Petrological and Geochemical Composition of Lignite from the D Field, Kolubara Basin (Serbia)", International Journal of Coal Geology, 2013, vol. 111., pp. 5-22.

[12] Farhaduzzaman, Md., Abdullah, Wan H., Islam, Md. A., "Depositional Environment and Hydrocarbon Source Potential of the Permian Gondwana Coals from the Barapukuria Basin, Northwest Bangladesh, International Journal of Coal Geology, 2012, vol. 90-91, pp. 162-179.

[13] Widodo, S., Bechtel, A., Anggayana, K., Puttmann, W., "Reconstruction of Floral Changes during Deposition of the Miocene Embalut Coal from Kutai Basin, Mahakam Delta, East Kalimantan, Indonesia by use of Aromatic Hydrocarbon Composition and Stable Carbon Isotope Ratios of Organic Matter", Organic Geochemistry, 2009, vol. 40, pp. 206-218.

[14] Summons, R. E., Volkman, J. K., dan Boreham, C. J., "Dinosterane and Other Steroidal Hydrocarbons of Dinoflagellate Origin in Sediments and Petroleum", Geochimica et Cosmochimica Acta, 1987, vol. 51, pp. 30753082.

[15] Silverstein, R. M., Webster, F. X., dan Kiemle, D. J., "Spectrometric Identification of Organic Compounds", Seventh Edition, John Wiley \& Sons, Inc. New York, 2005.

[16] Philp, R. P., "Fossil Fuel Biomarkers Application and Spectra", Elsevier, U.S.A, 1985.

[17] Simoneit, B. R. T., "Biomarkers (Molecular Fossils) as Geochemical Indicators of Life", Advances in Space Research, 2004, vol. 33, pp. 1255-1261.

[18] Ogihara, S., “Acyclic Hydrocarbons and Ketones in Cold-seep Carbonates from Central Hokaido, Northern Japan”, Geochemical Journal, 2008, vol. 42, pp. 421-427.
[19] Azevedo, D. A., Zinu, C. J. A., Neto, F. R. A., Simoneit, B. R. T., "Possible Origin of Acyclic (Linear and Isoprenoid) and Tricyclic Terpane Methyl Ketones in a Tasmanian Tasmanite Bitumen", Organic Geochemistry, 2001, vol. 32, pp. 443-448.

[20] Rontani, J. F., Giral, P. J. P., Baillet, G., dan Raphel, D. "Bound" 6,10,14trimethylpentadecan-2-one: a Useful Marker for Photodegradation of Chlorophylls with a Phytol Ester Group in Seawater", Organic Geochemistry, 1992, vol. 18, pp. 139-142.

[21] Robinson, James W., Frame, Eileen M. S., Frame II, George M., "Undergraduate Instrumental Analysis", Sixth Edition, Marcel Dekker, New York, 1979.

[22] Fowler, M. G., Abolins, P., dan Douglas, A. G., "Monocyclic Alkanes in Ordovician Organic Matter", Organic Geochemistry, 1986, vol. 10, pp. 815-823.

[23] Ourisson, G., Albrecht, P., dan Rohmer, M., "The Hopanoids; Palaeochemistry and Biochemistry of A Group of Natural Products, Pure \& Appl. Chemistry, 1979, vol. 51, pp. 709-729.

[24] Tritz, J. P., Herrmann, D., Bisseret, P., Connan, J., dan Rohmer, M., "Abiotic and Biological Hopanoid Transformation: Towards the Formation of Molecular Fossils of the Hopane Series", Organic Geochemistry, 1999, vol. 30, pp. 499-514.

[25] Lopez, Jordi F., Oteyza, Tirso G. D., Teixidor, P., Grimalt, Joan O., "Long Chain Alkenones in Hypersaline and Marine Coastal Microbial Mats", Organic Geochemistry, 2010, vol. 36, pp. 861872.

[26] Burhan, R. Y. P., Trendel, J. M., Adam, P., Wehrung, P., Albrecht, P., dan Nissenbaum, A., "Fossil Bacterial Ecosystem at Methane Seep: Origin of Organic Matter from Be'eri Sulfur Deposit, Israel", Geochemica et Cosmochimica Acta, 2002, vol. 66, pp. 4085-4101. 